\title{
Supramolecular Arrangement in Styphnic Acid and Naphthalene-1,4-diol (1 : 1) through a Novel Synthetic Rote for Styphnic Acid
}

\author{
Moamen S. Refat, ${ }^{1,2}$ Hossam A. Saad, ${ }^{1,3}$ Mohamed Y. El-Sayed, ${ }^{3}$ \\ Abdel Majid A. Adam, ${ }^{1}$ Okan Zafer Yeşilel, ${ }^{4}$ and Murat Taş ${ }^{5}$ \\ ${ }^{1}$ Chemistry Department, Faculty of Science, Taif University, Al-Haweiah, P.O. Box 888, Taif 21974, Saudi Arabia \\ ${ }^{2}$ Department of Chemistry, Faculty of Science, Port Said University, Port Said, Egypt \\ ${ }^{3}$ Chemistry Department, Faculty of Science, Zagazig University, Zagazig, Egypt \\ ${ }^{4}$ Osman Gazi University, Art and Science Faculty, Department of Chemistry, Eskişehir, Turkey \\ ${ }^{5}$ Giresun University, Art and Science Faculty, Department of Chemistry, Giresun, Turkey
}

Correspondence should be addressed to Moamen S. Refat; msrefat@yahoo.com

Received 2 May 2013; Revised 1 July 2013; Accepted 2 July 2013

Academic Editor: Stojan Stavber

Copyright (C) 2013 Moamen S. Refat et al. This is an open access article distributed under the Creative Commons Attribution License, which permits unrestricted use, distribution, and reproduction in any medium, provided the original work is properly cited.

The chemical preparation and crystal structure of styphnic acid and naphthalene-1,4-diol (1:1) (I) have been reported. The compound crystallizes in the orthorhombic system in space group Pnma and cell parameters $a=6.6712(2), b=16.8267(7)$, $c=13.6450(5) \AA$ and $V=1531.71(10) \AA^{3}$, and $Z=4$. Crystal structure has been determined and refined to $R=0.0576$. The crystal structure of $\mathrm{I}$, the asymmetric unit, contains $\mathrm{C}_{6} \mathrm{H}_{2} \mathrm{~N}_{3} \mathrm{O}_{7}, \mathrm{C}_{10} \mathrm{H}_{7} \mathrm{O}$, and it is a half portion of both styphnic acid and naphthalene1,4-diol. The $\mathrm{O} 1-\mathrm{H} 1 \cdots \mathrm{O} 2$ intramolecular hydrogen bond was found between the $\mathrm{O}-\mathrm{H}$ and a nitro group in the styphnic acid unit.

\section{Introduction}

Many of the electron donor-acceptor (EDA) interactions had been widely studied spectrophotometrically in the determination of drugs that are easy to be determined based on CT-complex formation with some electron acceptors [1-3].

The study of the charge-transfer complexes formed in the reaction of aromatic electron acceptors ( $\pi$-acceptors) with various electron donors has attracted considerable interest, and growing importance owing to their significant, physical and chemical properties $[4,5]$. A vast number of the chargetransfer complexes formed during the reaction of $\sigma$ - and $\pi$-acceptors with organic compounds containing different sites of donation (nitrogen, oxygen or sulfur atoms) were extensively investigated [6-10]. This paper is a continuation of our previous investigation [11-14] concerned with the formation of stable charge-transfer complexes formed during the reaction of electron donors.

The picric acid (2,4,6-trinitrobenzene-1-ol) (2,4,6-trinitrophenol) and picrates can be used in explosive materials. 2,4,6-trinitrobenzene-1,3-diol is an analog of the picric acid and it is also known as styphnic acid, or trinitroresorcinol. With regard to explosive power and sensitiveness styphnic acid is similar to picric acid. Since, its price is considerably higher than that of picric acid, it is not used in explosive technology and only lead styphnate (lead trinitroresorcinate) is of great practical importance as an initiator. On the whole, the properties of styphnate salts are similar to those of picrates.

This paper describes the new synthesis route for the styphnic acid and naphtalene-1,4-diol reaction between picric 


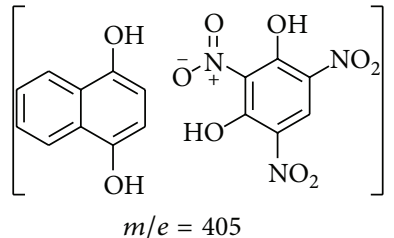<smiles>O=[N+]([O-])c1cc([N+](=O)[O-])c(O)c([N+](=O)[O-])c1O</smiles>

$m / e=245$<smiles>O=[N+]([O-])c1cc([N+](=O)[O-])c(O)c([N+](=O)[O-])c1</smiles>

$m / e=229$<smiles>Cc1cc2c(O)ccc(O)c2cc1O</smiles>

$m / e=389$<smiles>O=[N+]([O-])c1ccc(O)c([N+](=O)[O-])c1O</smiles>

$m / e=199$<smiles>Oc1cccc2ccccc12</smiles>

$m / e=144$

SCHEMe 1

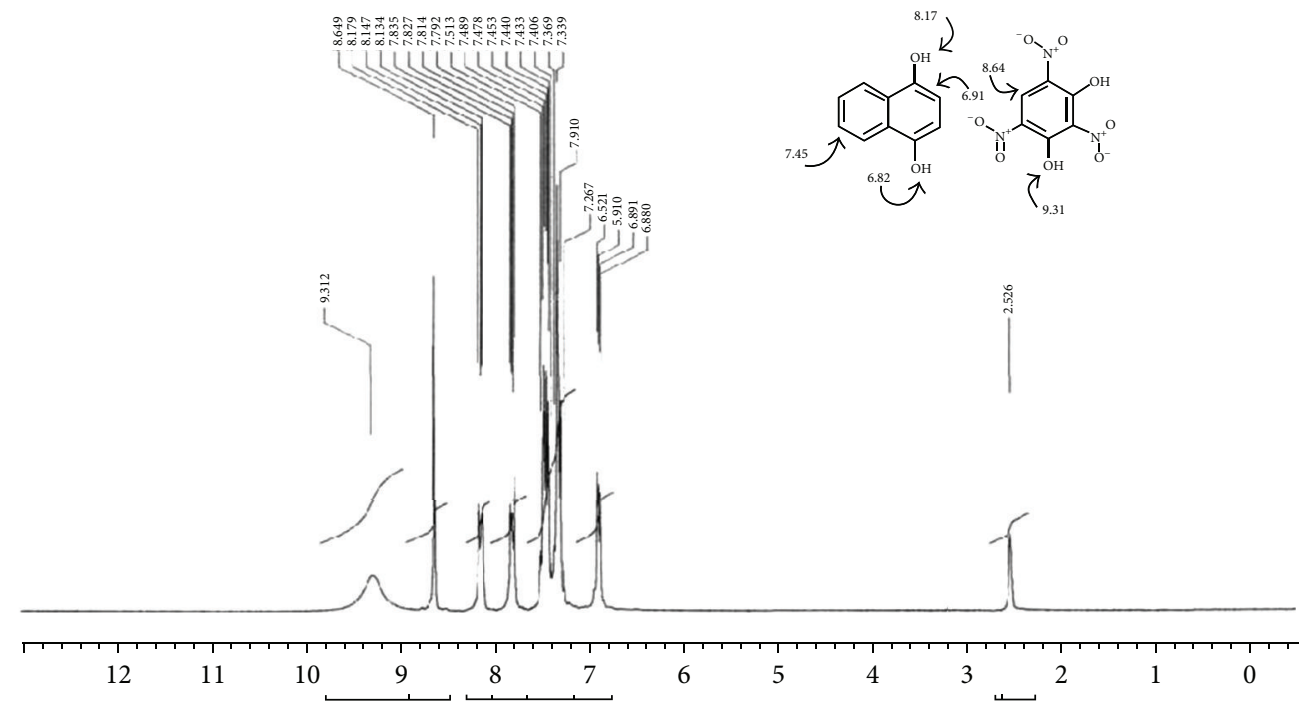

FIGURE 1: ${ }^{1} \mathrm{H}$ NMR spectrum of naphtalene-1,4-diol and styphnic acid complex.

acid ( $\pi$-acceptor) and naphtalene-1-ol ( $\alpha$-naphthol) (donor) and its cocrystal structure.

\section{Experimental}

To a solution of $\alpha$-naphthol (144 mg, $1 \mathrm{mmoL}$ ) in $10 \mathrm{~mL}$ of $\mathrm{CH}_{3} \mathrm{OH} / \mathrm{CHCl}_{3} 50 / 50 \mathrm{w} / \mathrm{w}$, a solution of picric acid (229 mg, $1 \mathrm{mmoL})$ in $\mathrm{CH}_{3} \mathrm{OH}(25 \mathrm{~mL})$ was added at room temperature. An orange red color developed and the solution was allowed to evaporate slowly at room temperature. Orange red crystals were formed, filtered off, and dried under vacuum. IR (KBr): (3444 and $\left.3294 \mathrm{~cm}^{-1}\right),\left(1577,1543\right.$, and $\left.1516 \mathrm{~cm}^{-1}\right)$, and $1343 \mathrm{~cm}^{-1}$ for $\nu(\mathrm{OH}), v_{\text {as }}\left(\mathrm{NO}_{3}\right)$, and $\nu_{\mathrm{s}}\left(\mathrm{NO}_{3}\right)$, respectively. ${ }^{1} \mathrm{H}$ NMR $\left(\mathrm{DMSO}-\mathrm{d}_{6}\right): \delta=6.91\left(\mathrm{~s}, 2 \mathrm{H}, \mathrm{H}_{2}\right.$ and $\mathrm{H}_{3}$, naphthalene ring), $7.45\left(\mathrm{dd}, 2 \mathrm{H}, \mathrm{H}_{6}\right.$ and $\mathrm{H}_{7}$, naphthalene ring), $\delta=6.82(\mathrm{~d}$, $2 \mathrm{H}, J=2.20 \mathrm{~Hz}, \mathrm{H}_{5}$ and $\mathrm{H}_{8}$, naphthalene ring), $8.17(\mathrm{~s}, 2 \mathrm{H}$, $2 \mathrm{OH}$, naphthalene ring), 8.64 ( $\mathrm{s}, 1 \mathrm{H}$, styphnic acid proton), and $9.31(\mathrm{~s}, 2 \mathrm{H}, 2 \mathrm{OH}$, styphnic acid $\mathrm{OH}) . \mathrm{MS} m / z=\mathrm{M}^{+}$(405), $389,245,229,199$, and 144 (Scheme 1).

\section{Results and Discussion}

It is well known that nitro group in picric acid is a strong oxidizing agent, and concerning picric acid that contains three of these nitro groups, we believed that, it is the source of the oxidation of the $\alpha$-naphthol along with itself to give naphtalene-1,4-diol and styphnic acid, respectively. Similar features of this kind of mechanisms were suggested earlier [15]. The reaction under investigation is a reaction between an electron-rich $\alpha$-naphthol and electron-poor picric acid in a methanol chloroform mixture as a solvent.

The ${ }^{1} \mathrm{H}$ NMR of the separated complex (Figure 1) revealed one singlet signal for the symmetrical $\mathrm{H}_{2}$ and $\mathrm{H}_{3}$ protons in 1,4-dihydroxynaphthalene at $\delta=6.91 \mathrm{ppm}$ along with one singlet signal for one proton in styphnic acid at $\delta=6.91 \mathrm{ppm}$.

The mass spectra (Figure 2) showed $m / e$ fragmentations $405,389,245,229,199$, and 144; the fragment expected for these fragmentations are as follows.

The IR spectrum (Figure 3) showed bands at (3444 and $\left.3294 \mathrm{~cm}^{-1}\right),\left(1577,1543\right.$ and $\left.1516 \mathrm{~cm}^{-1}\right)$, and $1343 \mathrm{~cm}^{-1}$ assigned to $v(\mathrm{OH}), v_{\text {as }}\left(\mathrm{NO}_{2}\right)$, and $\nu_{\mathrm{s}}\left(\mathrm{NO}_{2}\right)$, respectively. 


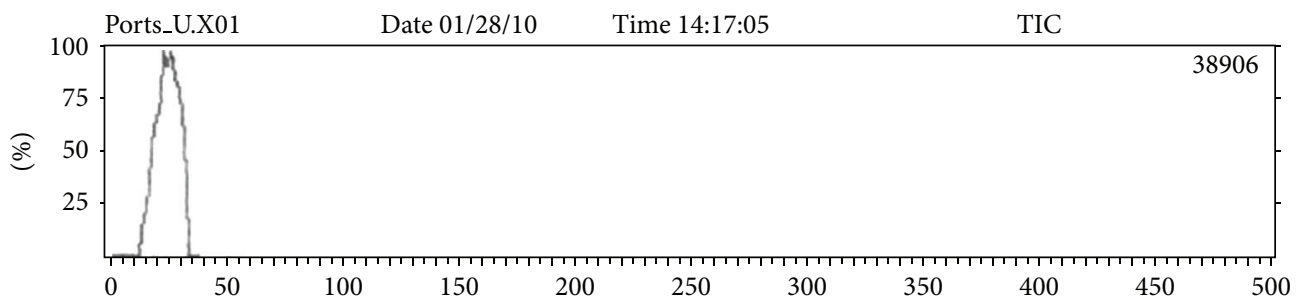

(a)

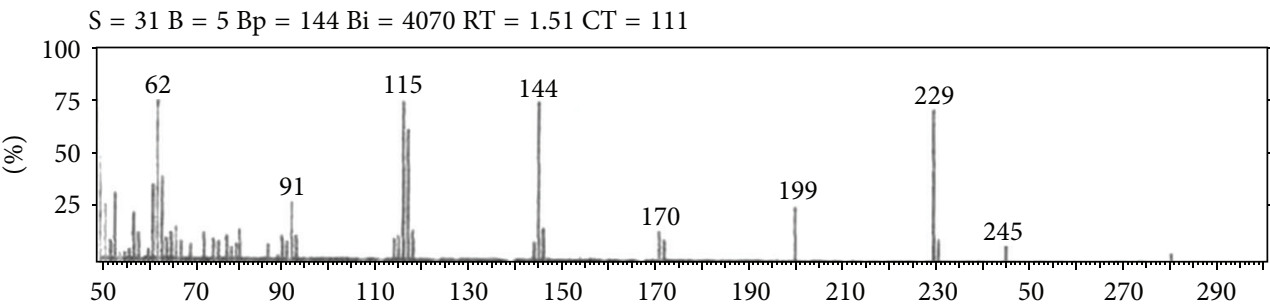

(b)

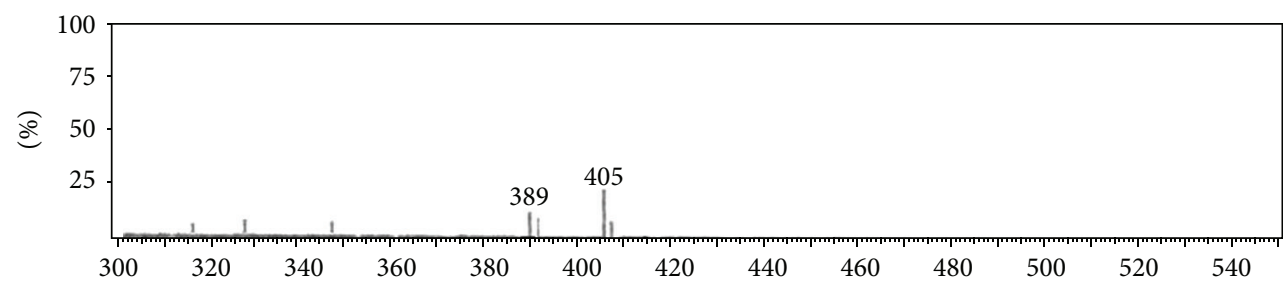

S list $\rightarrow \mathrm{S}=31 \mathrm{~B}=5$ Pos $=4$ Tot $=4$

(c)

FIGURE 2: Mass spectrum of naphtalene-1,4-diol and styphnic acid complex.

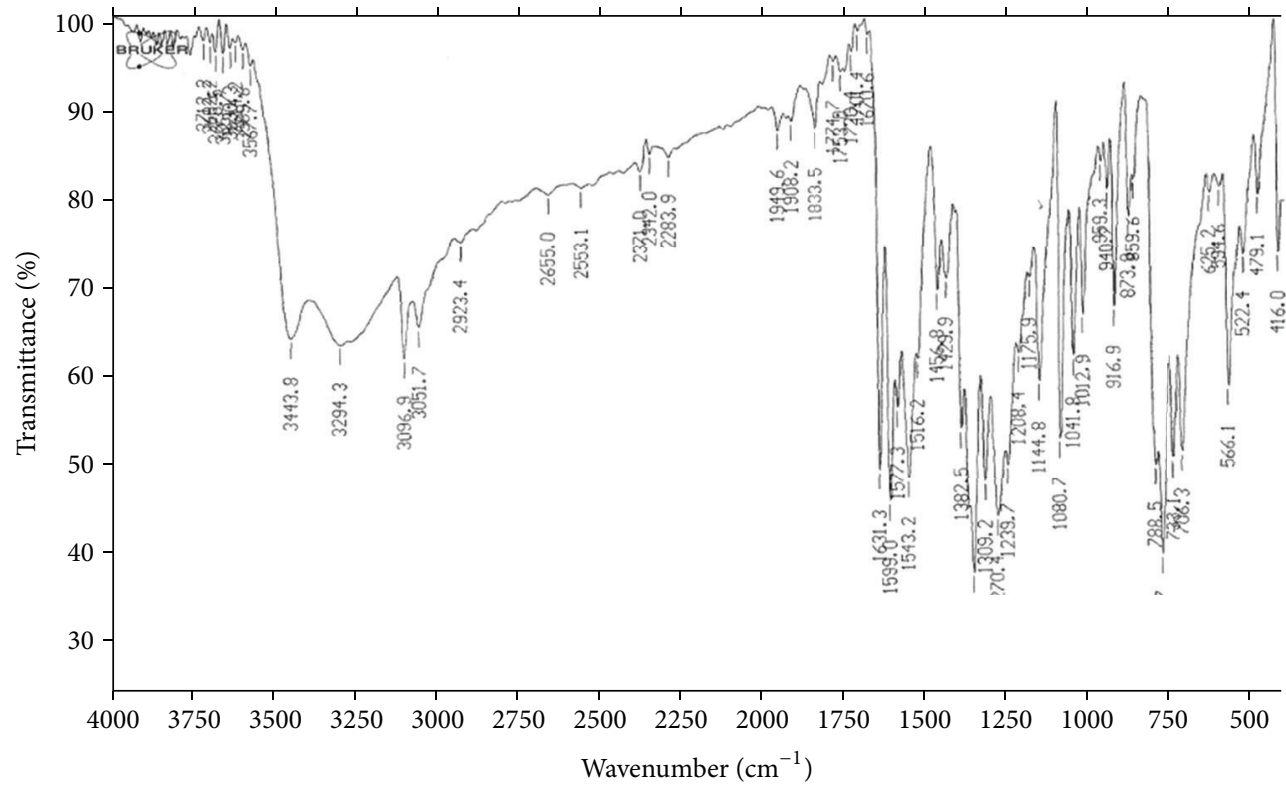

Figure 3: Infrared spectrum of naphtalene-1,4-diol and styphnic acid complex. 
TABLE 1: Crystal data and structure refinement for the compound.

\begin{tabular}{|c|c|}
\hline \multicolumn{2}{|c|}{ Crystal data } \\
\hline Formula & $\mathrm{C}_{6} \mathrm{H}_{2} \mathrm{~N}_{3} \mathrm{O}_{7}, \mathrm{C}_{10} \mathrm{H}_{7} \mathrm{O}$ \\
\hline Formula weight & 371.26 \\
\hline Crystal system & Orthorhombic \\
\hline Space group & Pnma \\
\hline$a, b, c[$ Angstrom $]$ & $\begin{array}{c}6.6712(2) \\
16.8267(7) \\
13.6450(5)\end{array}$ \\
\hline$V\left[\AA^{3}\right]$ & $1531.71(10)$ \\
\hline$Z$ & 4 \\
\hline$D($ calc $)\left[\mathrm{g} / \mathrm{cm}^{3}\right]$ & 1.610 \\
\hline$\mu(\mathrm{Mo}-\mathrm{K} \alpha)\left[\mathrm{mm}^{-1}\right]$ & 0.133 \\
\hline$F(000)$ & 760 \\
\hline Crystal size $[\mathrm{mm}]$ & $0.10 \times 0.15 \times 0.45$ \\
\hline \multicolumn{2}{|c|}{ Data collection } \\
\hline Temperature (K) & 173 \\
\hline Radiation $[\AA]$ & Mo-K $\alpha 0.71075$ \\
\hline Theta Min-Max $\left[^{\circ}\right]$ & $3.3,27.5$ \\
\hline Dataset & $0: 21 ; 0: 17 ; 0: 8$ \\
\hline Tot., Uniq. Data, $R$ (int) & $1821,1821,0.000$ \\
\hline Observed data $[I>2.0 \operatorname{sigma}(I)]$ & 1303 \\
\hline \multicolumn{2}{|c|}{ Refinement } \\
\hline Nref, Npar & 1821,156 \\
\hline$R, \mathrm{w} R 2, S$ & $0.0576,0.1637,1.10$ \\
\hline Max. and Av. Shift/Error & $0.00,0.00$ \\
\hline Min. and Max. Resd. Dens. [e/ $\left.\AA^{3}\right]$ & $-0.28,0.27$ \\
\hline
\end{tabular}

In the crystal structure of I, the asymmetric unit, contains $\mathrm{C}_{6} \mathrm{H}_{2} \mathrm{~N}_{3} \mathrm{O}_{7}, \mathrm{C}_{10} \mathrm{H}_{7} \mathrm{O}$, and it is a half of portion of both styphnic acid and naphtalene-1,4-diol. The O1-H1 $\cdots \mathrm{O} 2$ intramolecular hydrogen bond was found between the $\mathrm{O}-\mathrm{H}$ and a nitro group in the styphnic acid unit (Figure 4, Table 1).

The possibility of hydrogen bonds was explored for the synthesized compound by the statistical criterion proposed by Taylor and Kennard [15] and was found to be very effective in supramolecular arrangement of molecular units in the solid state. In the solid state, the naphtalene-1,4-diol part of the asymmetric unit acts as hydrogen bond donor via its $\mathrm{O} 5, \mathrm{C} 5, \mathrm{C} 8$, and $\mathrm{C} 9$ atoms to $\mathrm{O} 2, \mathrm{O} 3$, and $\mathrm{O} 4$ atoms of symmetry related styphnic acid parts which are explained below, to give three-dimensional network in supramolecular arrangement.

Along the $a$ axis, naphtalene-1,4-diol form infinite polymeric chains by $\mathrm{C} 5-\mathrm{H} 5 \cdots \mathrm{O} 2^{\mathrm{ii}}$ at $x+1 / 2, y,-z+1 / 2$ and $\mathrm{C} 9-$ $\mathrm{H} 9 \cdots \mathrm{O} 4^{\mathrm{iii}}$, at $x-1 / 2, y,-z+1 / 2$ hydrogen bonds (Figure 5, Table 1).

These two polymeric chains fit into one another by molecules in asymmetric unit so the polymeric chains are arranged approximately perpendicular to each other (Figure 7).

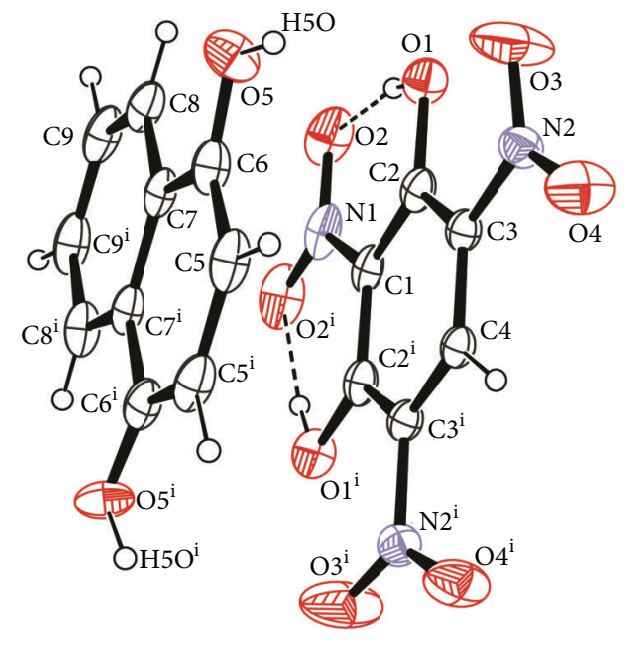

FIGURE 4: The asymmetric unit of the compound with the atomic labeling scheme. Displacement ellipsoids of non- $\mathrm{H}$ atoms are drawn at the $30 \%$ probability level.

The naphtalene-1,4-diol in the asymmetric unit bonds to styphnic acid at $-x+1 / 2,-y+1, z+1 / 2$ by the $\mathrm{O} 5-\mathrm{H} 5 \mathrm{O} \cdots \mathrm{O} 4^{\mathrm{v}}$ 
TABLE 2: Selected interatomic distances, angles, and hydrogen bond geometries $\left(\AA,^{\circ}\right)$.

(a)

\begin{tabular}{|c|c|c|c|}
\hline Bond & Lengths & Bond & Lengths \\
\hline $\mathrm{N} 1-\mathrm{C} 1$ & $1.457(4)$ & $\mathrm{C} 1-\mathrm{C} 2$ & $1.400(3)$ \\
\hline $\mathrm{N} 2-\mathrm{C} 3$ & $1.466(3)$ & $\mathrm{C} 1-\mathrm{C} 2^{\mathrm{i}}$ & $1.400(2)$ \\
\hline $\mathrm{O} 1-\mathrm{C} 2$ & $1.342(4)$ & $\mathrm{C} 2-\mathrm{C} 3$ & $1.397(3)$ \\
\hline $\mathrm{O} 1-\mathrm{H} 1$ & $0.89(5)$ & $\mathrm{C} 3-\mathrm{C} 4$ & $1.375(2)$ \\
\hline $\mathrm{O} 2-\mathrm{N} 1$ & $1.228(3)$ & $\mathrm{C} 4-\mathrm{H} 4$ & $1.09(3)$ \\
\hline $\mathrm{O} 3-\mathrm{N} 2$ & $1.183(3)$ & $\mathrm{C} 5-\mathrm{C}^{\mathrm{i}}$ & $1.405(4)$ \\
\hline $\mathrm{O} 4-\mathrm{N} 2$ & $1.212(3)$ & C5-C6 & $1.372(3)$ \\
\hline O5-C6 & $1.243(4)$ & C5-H5 & $0.94(3)$ \\
\hline $\mathrm{O} 5-\mathrm{H} 5 \mathrm{O}$ & 0.8400 & $\mathrm{C} 6-\mathrm{C} 7$ & $1.420(3)$ \\
\hline \multirow[t]{2}{*}{$\mathrm{C} 7-\mathrm{C} 8$} & $1.422(3)$ & $\mathrm{C} 7-\mathrm{C} 7^{\mathrm{i}}$ & $1.424(3)$ \\
\hline & Angles & & Angles \\
\hline N1-C1-C2 & $118.39(13)$ & $\mathrm{C} 1-\mathrm{C} 2-\mathrm{C} 3$ & $116.3(2)$ \\
\hline N2-C3-C2 & $119.56(18)$ & $\mathrm{C} 2-\mathrm{C} 1-\mathrm{C} 2^{\mathrm{i}}$ & $123.2(2)$ \\
\hline N2-C3-C4 & $117.56(18)$ & $\mathrm{C} 2-\mathrm{C} 3-\mathrm{C} 4$ & $122.9(2)$ \\
\hline $\mathrm{O} 1-\mathrm{C} 2-\mathrm{C} 1$ & $122.9(2)$ & $\mathrm{C} 3-\mathrm{C} 4-\mathrm{C} 3^{\mathrm{i}}$ & $118.4(2)$ \\
\hline $\mathrm{O} 1-\mathrm{C} 2-\mathrm{C} 3$ & $120.8(2)$ & C5-C6-C7 & $120.1(2)$ \\
\hline $\mathrm{O} 2-\mathrm{N} 1-\mathrm{C} 1$ & $118.41(14)$ & $\mathrm{C} 5^{\mathrm{i}}-\mathrm{C} 5-\mathrm{C} 6$ & $120.8(2)$ \\
\hline $\mathrm{O} 2-\mathrm{N} 1-\mathrm{O} 2^{\mathrm{i}}$ & $123.2(3)$ & $\mathrm{C} 6-\mathrm{C} 7-\mathrm{C} 7^{\mathrm{i}}$ & 119.19(19) \\
\hline $\mathrm{O} 3-\mathrm{N} 2-\mathrm{C} 3$ & 119.16(19) & C6-C7-C8 & $122.2(2)$ \\
\hline O3-N2-O4 & $123.2(2)$ & $\mathrm{C} 7-\mathrm{C} 8-\mathrm{C} 9$ & $120.7(2)$ \\
\hline $\mathrm{O} 4-\mathrm{N} 2-\mathrm{C} 3$ & $117.65(18)$ & $\mathrm{C} 7^{\mathrm{i}}-\mathrm{C} 7-\mathrm{C} 8$ & $118.63(19)$ \\
\hline O5-C6-C5 & $127.7(3)$ & $\mathrm{C} 8-\mathrm{C} 9-\mathrm{C} 9^{\mathrm{i}}$ & $120.6(2)$ \\
\hline $\mathrm{O} 5-\mathrm{C} 6-\mathrm{C} 7$ & $112.2(2)$ & C6-O5-H5O & 109 \\
\hline
\end{tabular}

(b)

\begin{tabular}{lcccc}
\hline$D-\mathrm{H} \cdots A$ & $D-\mathrm{H}$ & $\mathrm{H} \cdots A$ & $D \cdots A$ & $D-\mathrm{H} \cdots A$ \\
\hline $\mathrm{O} 1-\mathrm{H} 1 \cdots \mathrm{O} 2$ & $0.89(6)$ & $1.59(6)$ & $2.454(4)$ & $161(5)$ \\
$\mathrm{C} 5-\mathrm{H} 5 \cdots \mathrm{O} 2^{\text {ii }}$ & $0.94(3)$ & $2.69(2)$ & $3.379(3)$ & $131.2(18)$ \\
$\mathrm{C} 9-\mathrm{H} 9 \cdots 4^{\text {iii }}$ & $0.97(3)$ & $2.94(3)$ & $3.788(3)$ & $146.6(18)$ \\
$\mathrm{C} 8-\mathrm{H} 8 \cdots$ O1 $^{\text {iv }}$ & $0.91(3)$ & $2.68(3)$ & $3.432(5)$ & $141(2)$ \\
$\mathrm{C} 9-\mathrm{H} 9 \cdots 3^{\text {iv }}$ & $0.96(3)$ & $2.62(3)$ & $3.235(4)$ & $122.2(19)$ \\
$\mathrm{O} 5-\mathrm{H} 5 \mathrm{O} \cdots 4^{\mathrm{v}}$ & 0.84 & 1.99 & $2.790(3)$ & 160 \\
$\mathrm{C} 5-\mathrm{H} 5 \cdots 3^{\mathrm{v}}$ & $0.94(3)$ & $2.79(3)$ & $3.668(3)$ & $157(2)$ \\
$\mathrm{O}^{\mathrm{i}} \cdots \mathrm{H} 5 \cdots \mathrm{O}^{\mathrm{v}}$ & $2.69(2)$ & $2.79(3)$ & $3.051(2)$ & $67.65(18)$ \\
$\mathrm{O}^{\mathrm{i}} \cdots \mathrm{H} 9 \cdots 4^{\mathrm{iii}}$ & $2.62(3)$ & $2.94(3)$ & $3.698(3)$ & $83.14(18)$ \\
\hline
\end{tabular}

i: $x, 1 / 2-y, z$; ii: $x+1 / 2, y,-z+1 / 2$; iii: $x-1 / 2, y,-z+1 / 2$; iv: $-x,-y+1,-z+1$; v: $-x+1 / 2,-y+1, z+1 / 2$.

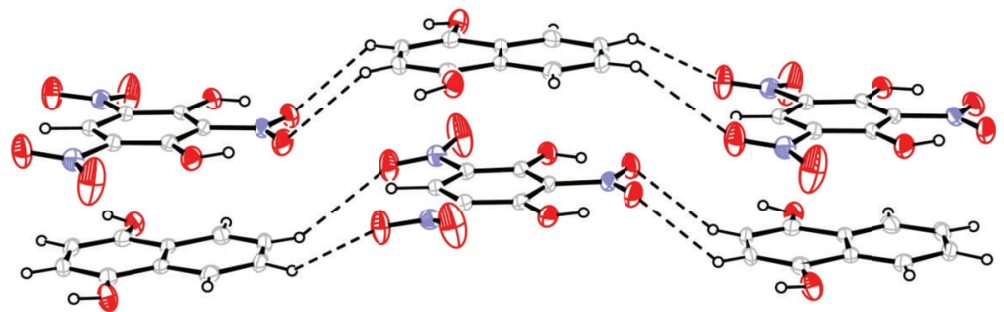

Figure 5: The view of infinite polymeric chains along the $a$ axis. Also, C8-H8 $\cdots$ O $1^{\text {iv }}$ and $\mathrm{C} 9-\mathrm{H} 9 \cdots \mathrm{O} 3^{\text {iv }}$ at $-x,-y+1,-z+1$ intermolecular hydrogen bonds form infinite polymeric chain along the $b$ axis (Figure 6, Table 1). 


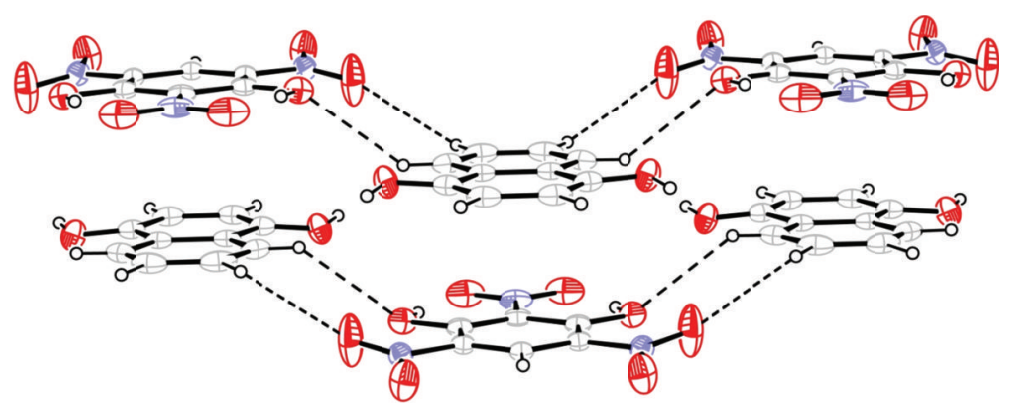

FIgURE 6: The view of infinite polymeric chains along the $b$ axis.

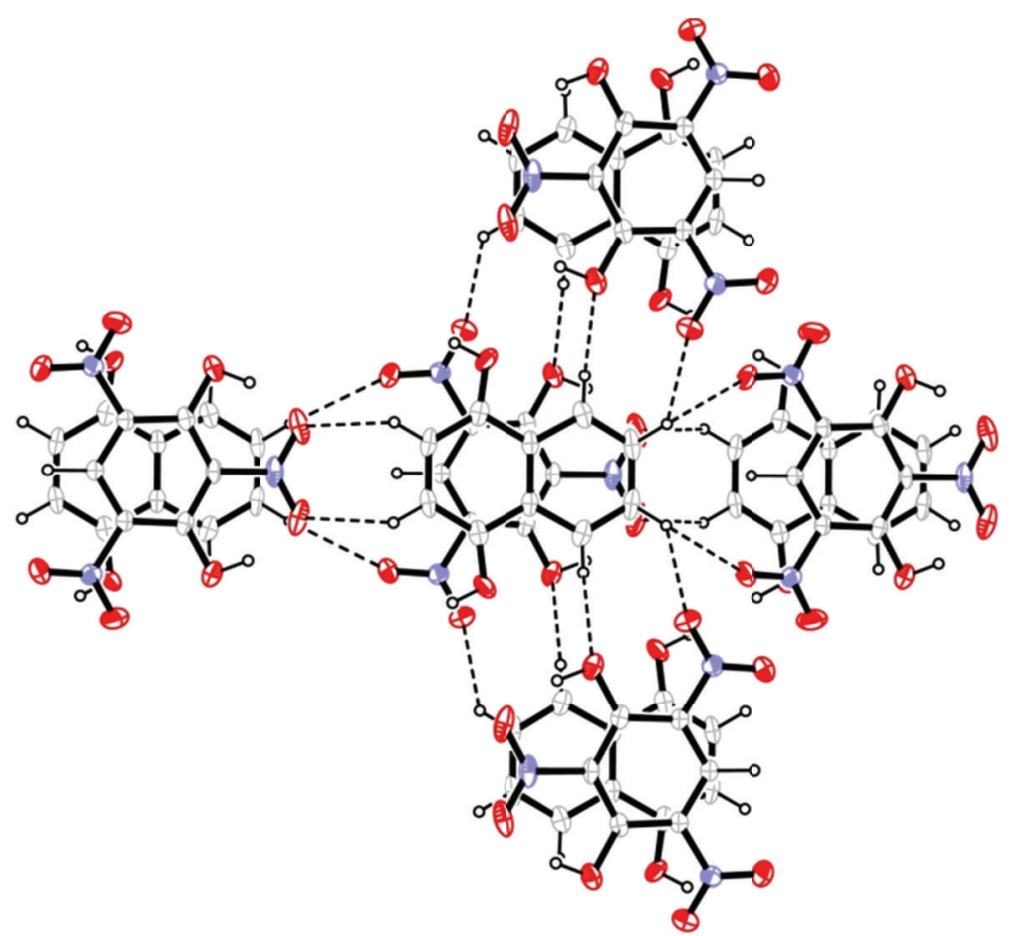

FIGURE 7: The arrangement of polymeric chains along $a$ and $b$ axis.

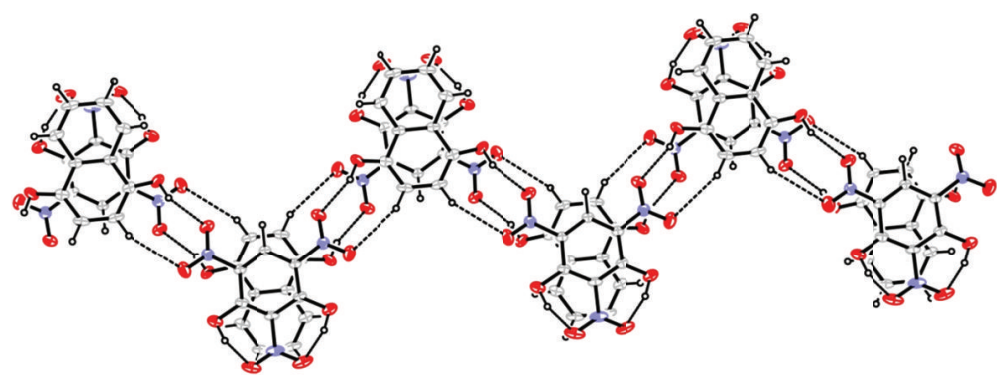

FIGURE 8: Forming of polymeric chains lying parallel to the [010] plane.

and $\mathrm{C} 5-\mathrm{H} 5 \cdots \mathrm{O}^{\mathrm{v}}{ }^{\mathrm{v}}$ intermolecular hydrogen bonds to form polymeric chains lying parallel to the [010] plane (Figure 8, Table 2).

The C5 and C9 atoms of naphtalene-1,4-diol in the asymmetric unit act as bifurcated hydrogen bond donors via their $\mathrm{H} 5$ and $\mathrm{H} 9$ either to form polymeric chains along the $b$ and $a$ axes or to extend the these chains through the $c$ axis so the polymeric chains bond to each other by $\mathrm{O} 2^{\mathrm{ii}} \cdots \mathrm{H} 5 \cdots \mathrm{O} 3^{\mathrm{v}}$ and ${ }^{\mathrm{Oiv}} \cdots \mathrm{H} 9 \cdots \mathrm{O} 4^{\text {iii }}$ bifurcated hydrogen bonds, respectively (Figure 9, Table 2).

Also, there were found some $\pi \cdots \pi$ interactions between the rings of naphtalene-1,4-diol and the rings of styphnic acid through the $c$ axis (Figure 10) to contribute to supramolecular arrangement in the solid state (Figure 11). 


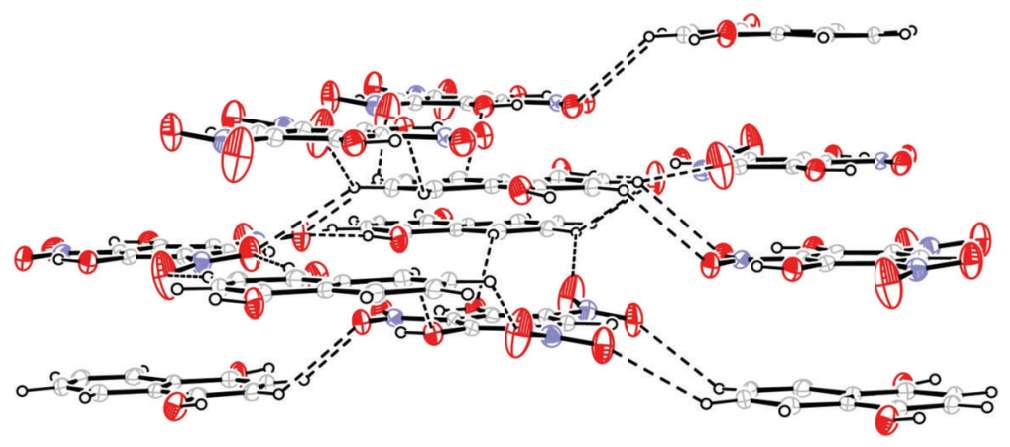

Figure 9: The view of bifurcated hydrogen bonds.

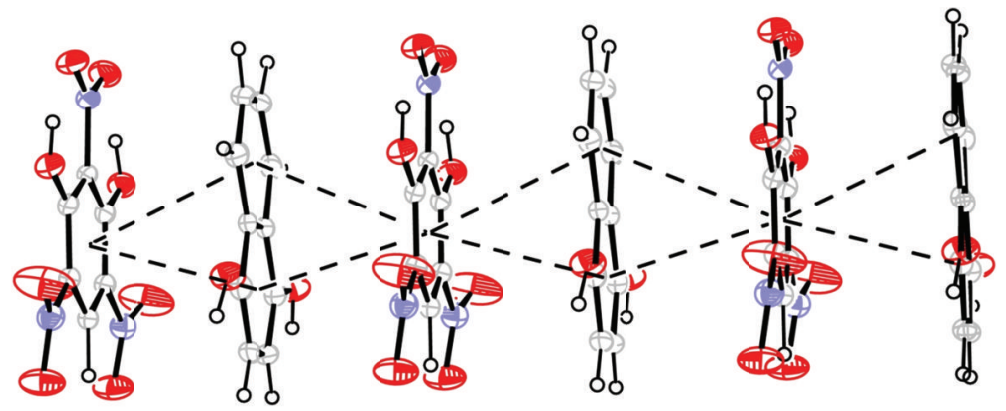

FIgURE 10: The $\pi \cdots \pi$ interactions in the molecules along the $c$ axis.

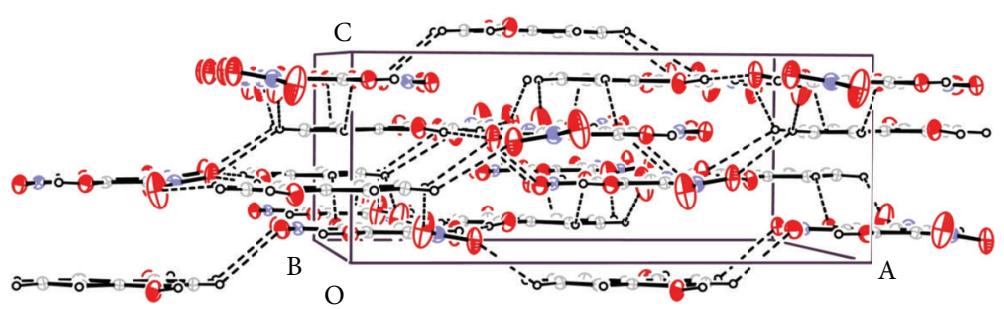

FIGURE 11: A packing diagram of the molecules; the $\pi \cdots \pi$ interaction was omitted for clarity.

\section{References}

[1] M. Pandeeswaran, E. H. El-Mossalamy, and K. P. Elango, "Spectroscopic studies on the interaction of cilostazole with iodine and 2,3-dichloro-5,6-dicyanobenzoquinone," Spectrochimica Acta, vol. 78, no. 1, pp. 375-382, 2011.

[2] C. Balraj, K. Ganesh, and K. P. Elango, "Structural characterization of molecular complexes formed by trimethoprim and cimitidine with 2,3,5,6-tetrachloro-1,4-benzoquinone," Journal of Molecular Structure, vol. 998, no. 1-3, pp. 110-118, 2011.

[3] U. M. Rabie, M. H. M. Abou-El-Wafa, and H. Nassar, "In vitro simulation of the chemical scenario of the action of an anti-thyroid drug: charge transfer interaction of thiazolidine-2thione with iodine," Spectrochimica Acta, vol. 78, no. 1, pp. 512517, 2011.

[4] C. S. P. Sastry, B. S. Sastry, J. V. Rao, and R. R. Krishna, "Spectrophotometric methods for the determination of tolnaftate," Talanta, vol. 40, no. 4, pp. 571-576, 1993.

[5] C. S. P. Sastry, K. R. Rao, and D. S. Prasada, "Determination of cefadroxil by three simple spectrophotometric methods using oxidative coupling reactions," in Microchimica Acta, vol. 126, pp. 1167-2172, 1997.
[6] E. L. Rimmer, R. D. Bailey, W. T. Pennington, and T. W. Hanks, "The reaction of iodine with 9-methylacridine: formation of polyiodide salts and a charge-transfer complex," Journal of the Chemical Society. Perkin Transactions 2, no. 11, pp. 2557-2562, 1998.

[7] B. B. Bhowmik and A. Bhattacharyya, "Solvent effects on charge-transfer intensities and heats of formation of chloranil complexes with aromatic hydrocarbons," Spectrochimica Acta, vol. 44, no. 11, pp. 1147-1151, 1988.

[8] R. M. Ramadan, A. M. El-Atrash, A. M. A. Ibrahim, and S. E. H. Etaiw, "The direct current electrical conductivity of the charge transfer complexes of some thiazoles and benzothiazoles with certain di- and trinitrobenzene derivatives," Thermochimica Acta, vol. 178, no. C, pp. 331-338, 1991.

[9] A. E. Mourad and A. M. Nour El-Din, "p-p Molecular complexes of [2.2.2] $(1,2,4)$ cyclophane and its methylated derivative with p-acceptors," Spectrochimica Acta, vol. 39, no. 3, pp. 289-292, 1983.

[10] R. Rathore, S. V. Lindeman, and J. K. Kochi, "Charge-transfer probes for molecular recognition via steric hindrance in donoracceptor pairs," Journal of the American Chemical Society, vol. 119, no. 40, pp. 9393-9404, 1997. 
[11] S. M. Teleb and M. S. Refat, "Spectroscopic studies on chargetransfer complexes formed in the reaction of ferric(III) acetylacetonate with $\sigma$ - and $\pi$-acceptors," Spectrochimica Acta, vol. 60, no. 7, pp. 1579-1586, 2004.

[12] E.-M. Nour, S. M. Teleb, M. A. F. Elmosallamy, and M. S. Refat, "Spectrophotometric and thermal studies of the reaction of iodine with nickel(II) acetylacetonate," South African Journal of Chemistry, vol. 56, pp. 10-14, 2003.

[13] M. S. Refat, S. M. Teleb, and I. Grabchev, "Charge-transfer interaction of iodine with some polyamidoamines," Spectrochimica Acta, vol. 61, no. 1-2, pp. 205-211, 2005.

[14] M. S. Refat, S. M. Aqeel, and I. K. Grabtchev, "Spectroscopic and physicochemical studies of charge-transfer complexes of some benzanthrone derivatives "luminophore dyes" with iodine as a - Acceptor," Canadian Journal of Analytical Sciences and Spectroscopy, vol. 49, no. 4, pp. 258-265, 2004.

[15] R. Taylor and O. Kennard, "Crystallographic evidence for the existence of $\mathrm{CH}-\mathrm{O}, \mathrm{CH}-\mathrm{N}$ and $\mathrm{CH}-\mathrm{Cl}$ hydrogen bonds," Journal of the American Chemical Society, vol. 104, no. 19, pp. 5063-5070, 1982. 

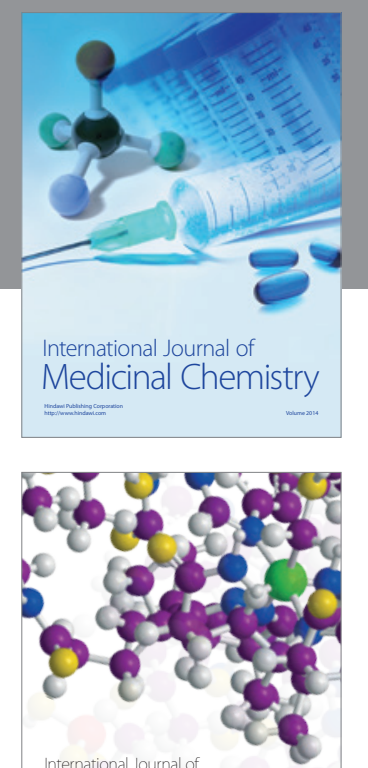

\section{Carbohydrate} Chemistry

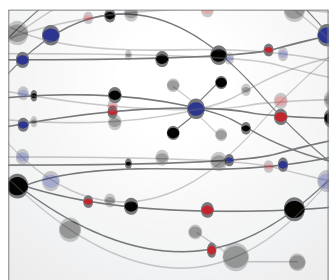

The Scientific World Journal
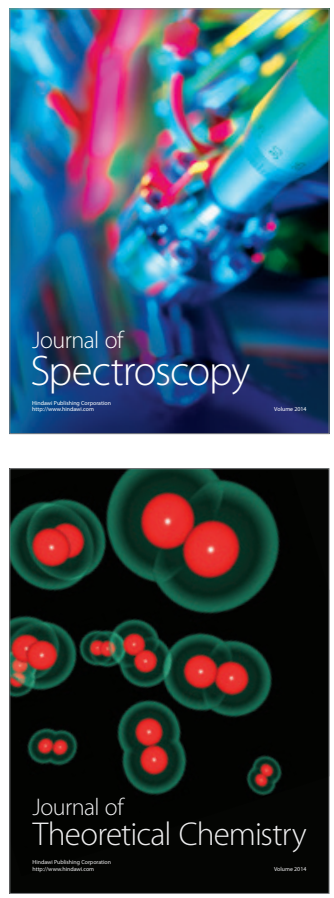
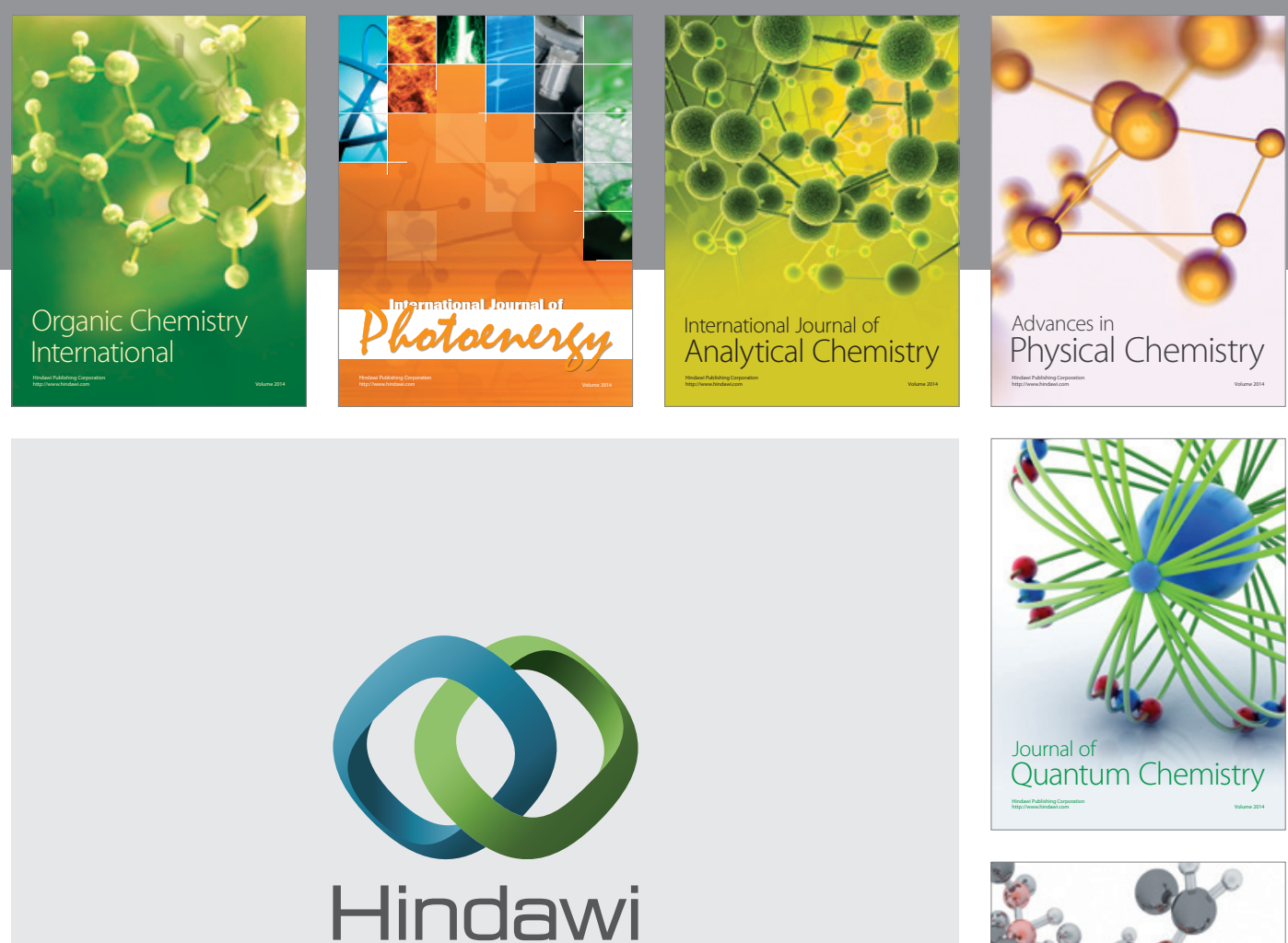

Submit your manuscripts at

http://www.hindawi.com

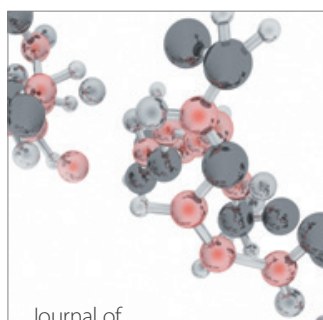

Analytical Methods

in Chemistry

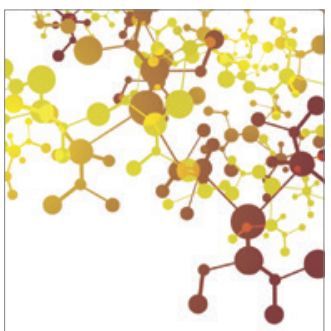

Journal of

Applied Chemistry

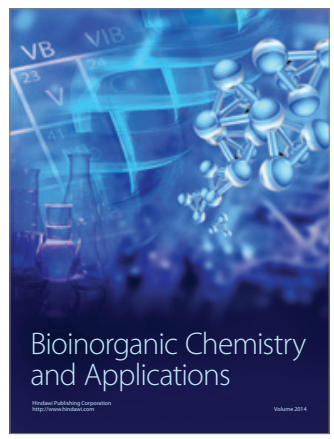

Inorganic Chemistry
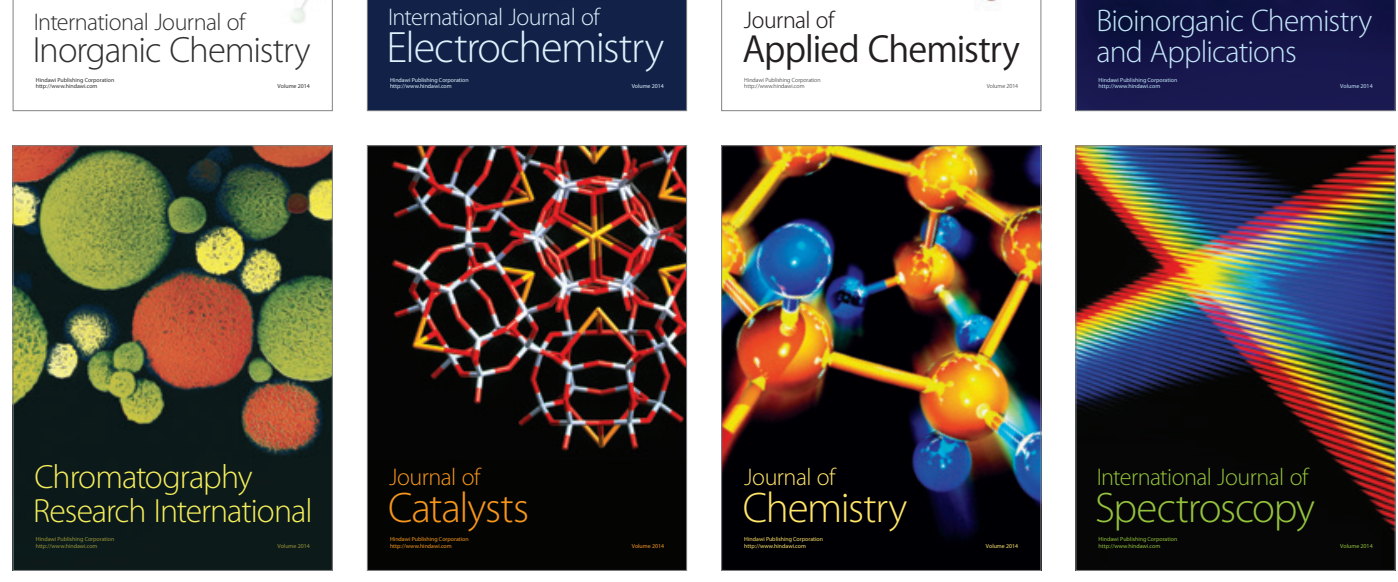